\title{
PENERAPAN MODEL PROBLEM BASED LEARNING (PBL) UNTUK MENINGKATKAN KINERJA ILMIAH DAN PENGUASAAN KONSEP SAINS SISWA KELAS VIII C SMP NEGERI 3 SINGARAJA TAHUN AJARAN 2010/2011
}

\author{
${ }^{1}$ N.W. S. Darmayanti, ${ }^{2}$ I.W. Suastra, ${ }^{3}$ R. Sujanem \\ 1Dosen Program Studi Pendidikan Fisika, Universitas Muhammadiyah Mataram \\ ${ }^{2,3}$ Jurusan Pendidikan Fisika, Fakultas Matematika Dan Pengetahuan Alam \\ Universitas Pendidikan Ganesha, Singaraja, Indonesia \\ Email : wyndarmayanti@gmail.com
}

\begin{abstract}
ABSTRAK
Penelitian ini dilatarbelakangi oleh rendahnya pencapaian hasil belajar siswa yang mencakup nilai penguasaan konsep sains dan kinerja ilmiah siswa kelas VIII C SMP Negeri 3 Singaraja tahun ajaran 2010/2011. Penelitian ini bertujuan untuk, 1) meningkatkan kinerja ilmiah siswa, 2) meningkatkan penguasaan konsep siswa, dan 3) mendeskripsikan tanggapan siswa terhadap penerapan model PBL dalam pembelajaran sains. Penelitian ini tergolong penelitian tindakan kelas (classroom action research). Subjek penelitian ini adalah siswa kelas VIII C SMP Negeri 3 Singaraja tahun ajaran 2010/2011. Data dikumpulkan melalui LKS, kuis, tugas, dan tes penguasaan konsep untuk penguasaaan konsep siswa. Data kinerja ilmiah siswa dikumpulkan dengan lembar observasi kinerja ilmiah dan data tanggapan siswa dikumpulkan dengan angket tanggapan siswa. Data yang diperoleh dari penelitian dianalisis secara deskriptif. Hasil dari penelitian ini menunjukkan bahwa, 1) Terjadi peningkatan kinerja ilmiah siswa. Pada siklus I, nilai rata-rata kinerja ilmiah siswa sebesar 67,9. Pada siklus II, nilai rata-rata kinerja ilmiah siswa sebesar 79,9. 2) Terjadi peningkatan penguasaan konsep siswa. Pada siklus I, diperoleh nilai rata-rata penguasaan konsep sebesar 72,6. Pada siklus II, diperoleh nilai rata-rata penguasaan konsep sebesar 75,5. 3) Tanggapan siswa terhadap penerapan model PBL positif dengan skor rata-rata 56,9. Hasil analisis data tersebut menunjukkan bahwa penerapan model PBL dapat meningkatkan kinerja ilmiah dan penguasaan konsep sains siswa kelas VIII C SMP Negeri 3 Singaraja tahun ajaran 2010/2011.
\end{abstract}

Kata Kunci: Model PBL, kinerja ilmiah, penguasaan konsep

\section{PENDAHULUAN}

Pada era persaingan global, Indonesia memerlukan sumber daya manusia berkualitas, yaitu manusia cerdas, sehat, jujur, berakhlak mulia, berkarakter, memiliki kepedulian sosial tinggi serta mampu beradaptasi dengan perkembangan IImu Pengetahuan Teknologi dan Seni (IPTEKS). Peningkatan mutu pendidikan adalah kunci utama untuk pengembangan sumber daya manusia dan pembentukan karakter dalam menentukan nasib bangsa. Pendidikan sains merupakan salah satu aspek pendidikan dengan menggunakan sains sebagai alatnya untuk mencapai tujuan pendidikan pada umumnya (Dantes et al., 2005).

IPA (sains) merupakan suatu kumpulan pengetahuan yang tersusun secara sistematis, dalam penggunaannya secara umum terbatas pada gejala-gejala alam. Merujuk pada pengertian sains tersebut, maka hakikat sains meliputi empat unsur, yaitu (1) produk yaitu berupa fakta, prinsip, teori, dan hukum, (2) proses yaitu prosedur pemecahan masalah melalui metode ilmiah, metode ilmiah meliputi pengamatan, penyusunan hipotesis, perancangan eksperimen, percobaan atau penyelidikan, pengujian hipotesis melalui eksperimen, evaluasi, pengukuran, dan penarikan kesimpulan, (3) aplikasi yaitu penerapan metode atau kerja ilmiah dan konsep sains dalam kehidupan sehari-hari, dan (4) sikap yaitu rasa ingin tahu tentang obyek, fenomena alam, makhluk hidup, serta hubungan sebab akibat yang menimbulkan masalah baru yang dapat dipecahkan melalui prosedur yang benar yaitu sains bersifat open ended (Puskur, 2007).

Pada proses pembelajaran sains, keterlibatan keempat unsur ini diharapkan membentuk peserta didik yang memiliki keterampilan ilmiah atau kinerja ilmiah. Pembelajaran sains harus mampu menciptakan peluang kepada pebelajar untuk memperoleh pengetahuannya sendiri melalui proses ilmiah sehingga mereka dapat mengembangkan dan 
mengaplikasikan pengetahuannya dalam memecahkan masalah yang dihadapinya.

Fisika adalah salah satu unsur sains yang berperanan penting dalam pengembangan teknologi masa depan. Fisika diperlukan untuk perkembangan pembangunan bagi kesejahteraan manusia. Dengan demikian, diperlukan sejumlah metode yang mampu mengantarkan siswa pada tahap penguasaan konsep-konsep fisika sehingga masalah tentang fisika dapat dipecahkan. Hal ini menunjukkan bahwa pelajaran fisika bukanlah pelajaran hafalan tetapi lebih menuntut pemahaman konsep bahkan aplikasi konsep tersebut (Sugiharti, 2005).

Berbagai upaya telah dilakukan pemerintah untuk meningkatkan kualitas pendidikan khususnya pendidikan sains. Salah satu cara yang telah dilakukan oleh Departemen Pendidikan Nasional adalah melakukan pembaharuan pada kurikulum dengan menerapkan Kurikulum Tingkat Satuan Pendidikan (KTSP) yang merupakan hasil revisi dari Kurikulum Berbasis Kompetensi (KBK) (Sanjaya, 2009). Selain itu, menurut Brahim (2007), dalam upaya meningkatkan kualitas pendidikan, kebijakan telah dilakukan oleh pemerintah Indonesia misalnya dengan perbaikan sarana dan prasarana, penataran, dan pelatihan serta inovasi pembaharuan metode pembelajaran.

Upaya-upaya tersebut diharapkan dapat meningkatkan kualitas pendidikan sains. Namun, kenyataan di lapangan menunjukkan bahwa apa yang diharapkan belum terlaksana secara optimal. Hal ini sesuai dengan apa yang peneliti temukan di SMP Negeri 3 Singaraja. Hasil belajar menunjukkan belum optimal. Hasil belajar yang dimaksudkan mencakup nilai penguasaan konsep dan kinerja ilmiah siswa yang merupakan tuntutan kurikulum dalam KTSP.

Berdasarkan observasi awal yang dilakukan di SMP Negeri 3 Singaraja, terungkap bahwa nilai rata-rata Ulangan Akhir Semester (UAS) dan kinerja ilmiah siswa kelas VIII seperti pada Tabel 1 danTabel 2.
Tabel 1. Nilai UAS Pada Semester Ganjil

\begin{tabular}{lllllll}
\hline \multirow{2}{*}{ Aspek } & \multicolumn{5}{c}{ KIs } \\
& \multicolumn{7}{c}{ VIII } & VIII & VIII & VIII & VIII & VIII \\
& A & B & C & D & E & F \\
\hline Nilai & & 70, & 62, & 65, & 63, & 65, \\
rata- & 67, & 56 & 84 & 38 & 25 & 18 \\
rata & 35 & & & & & \\
kelas & & & & & & \\
KKM & 64, & 64, & 64, & 64, & 64, & 64, \\
& 00 & 00 & 00 & 00 & 00 & 00 \\
Ketunta & & 79, & 63, & 69, & 67, & 66, \\
san & 70, & 48 & 16 & 23 & 50 & 67 \\
klasikal & 00 & & & & & \\
(\%) & & & & & & \\
\hline
\end{tabular}

Tahun Ajaran 2010/2011

Tabel 2. Nilai Kinerja Ilmiah Pada Semester Ganjil Tahun Ajaran 2010/2011

\begin{tabular}{lcccccc}
\hline \multirow{2}{*}{ Aspek } & \multicolumn{6}{c}{ Kinerja IImiah } \\
\cline { 2 - 7 } & VIII & VIII & VIII & VIII & VIII & VIII \\
& A & B & C & D & E & F \\
\hline Nilai & & 68, & 67, & 67, & 68, & 68, \\
rata- & 69,2 & 87 & 42 & 75 & 50 & 15 \\
rata & 5 & & & & & \\
kelas & & & & & & \\
KKM & 64,0 & 64, & 64, & 64, & 64, & 64, \\
& 0 & 00 & 00 & 00 & 00 & 00 \\
Ketunt & & & 73, & 77, & 75, & 76, \\
asan & 77,5 & 79, & 68 & 5 & 00 & 92 \\
klasikal & 0 & 48 & & & & \\
(\%) & & & & & & \\
\hline
\end{tabular}

(Sumber: Arsip nilai kelas VIII C SMP Negeri 3 Singaraja tahun 2011)

Berdasarkan Tabel 1 dan Tabel 2 ketuntasan klaksikal semua kelas VIII di SMP Negeri 3 Singaraja belum tuntas. Siswa kelas VIII dianggap tuntas apabila ketuntasan klasikal 85\%. Kriteria Ketuntasan Minimal (KKM) mata pelajaran sains untuk kelas VIII SMP Negeri 3 Singaraja adalah $\geq 64$. Rata-rata untuk nilai UAS dan kinerja ilmiah sudah tergolong cukup yang terdapat pada rentangan (56-69). Kelas VIII C 
memiliki rata-rata nilai UAS dan kinerja ilmiah paling rendah, serta ketuntasan klaksikal yang paling rendah jika dibandingkan dengan kelas VIII yang lainnya.

Berdasarkan hal tersebut, maka peneliti memilih kelas VIII C sebagai kelas yang akan diteliti. Siswa kelas VIII C dikatakan belum mencapai ketuntasan secara individual. Hasil belajar yang terdiri dari aspek penguasaan konsep dan kinerja ilmiah siswa perlu ditingkatkan lagi. Ada beberapa hal yang yang diidentifikasi sebagai faktor penyebab belum optimalnya hasil belajar yaitu pada aspek penguasaan konsep dan kinerja ilmiah siswa adalah sebagai berikut.

Pertama, pembelajaran sains di SMP Negeri 3 Singaraja masih didominasi oleh guru dalam proses pembelajaran sehingga keterlibatan siswa dalam proses pembelajaran masih kurang. Kedua, dalam proses pembelajaran, materi pelajaran kurang dikaitkan dengan masalah-masalah dunia nyata sebagai bahan yang dikaji di dalam kelas sehingga siswa menganggap sains itu bersifat abstrak dan disertai dengan rumusan matematika yang rumit, maka terkesan membosankan. Siswa sangat sulit dalam memahami dan menerapkan konsep-konsep sains sehingga bermuara pada rendahnya penguasaan konsep siswa.

Ketiga, siswa cenderung sebagai pebelajar yang bersifat pasif yang hanya mendengarkan penjelasan dari guru. Kurangnya pembentukan kelompok-kelompok kecil mengakibatkan interaksi dan soaialisasi siswa dengan temantemannya pada proses pembelajaran menjadi kurang. Pelaksanaan pembelajaran sains jarang menggunakan kegiatan praktikum. yang nantinya berimplikasi pada rendahnya kinerja ilmiah siswa. Keempat, evaluasi pembelajaran belum optimal. Keberhasilan siswa cenderung lebih banyak dinilai dari aspek kognitif, sedangkan aspek kinerja ilmiah belum dinilai secara maksimal. Hal itu disebabkan guru sulit menilai kinerja ilmiah karena siswanya cukup banyak.

Menurut kurikulum KTSP, penilaian hasil belajar tersebut terkait dengan aspek penguasaan konsep dan kinerja ilmiah. Berdasarkan permasalahan tersebut terlihat bahwa pembelajaran di SMP Negeri 3 Singaraja kelas VIII C masih bersifat teacher centred siswa memiliki kesulitan dalam penguasaan konsep-konsep sains. Pada proses pembelajaran sains, siswa jarang diajak praktikum akibatnya rendahnya kinerja ilmiah siswa. Siswa jarang berkelompok serta jarang diberikan masalah terkait dengan dunia nyata sebagai motivasi siswa dalam belajar. Dari masalah- masalah tersebut, maka pada proses pembelajaran sains yang dilaksanakan di sekolah seharusnya lebih ke arah student centered yang sesuai dengan pandangan konstruktivistik bahwa siswalah yang mengkonstruksi pengetahuannya sendiri. Hal tersebut dapat dilakukan dengan penerapan model pembelajaran inovatif yang mampu meningkatkan penguasaan konsep dan kinerja ilmiah siswa.

Model pembelajaran yang dimaksud adalah model pembelajaran Problem Based Learning (PBL). Sesuai dengan karakteristik model PBL menurut Barrows (dalam Selçuk, 2010) adalah sebagai berikut. (1) Belajar berpusat pada siswa. (2) Bentuk belajar siswa adalah dalam bentuk kelompok-kelompok kecil. (3) Guru bertindak sebagai moderator dan fasilitator. (4) Memberikan suatu masalah untuk motivasi belajar. (5) Memberikan masalah dasar untuk kemajuan pemecahan masalah. (6) Belajar mandiri dalam memperoleh informasi baru. PBL digambarkan sebagai model pembelajaran konstruktivis didasarkan pada asumsi bahwa belajar adalah sebuah produk kognitif dan interaksi sosial yang berasal dari masalah lingkungan. Siswa dapat memperkirakan bagaimana cara memecahkan masalah melalui mencari sumber-sumber terkait sehingga siswa menemukan sendiri cara pemecahan masalahnya. Hal tersebut akan berimplikasi pada peningkatan penguasaan konsep siswa.

Sesuai dengan tahapan-tahapan dari PBL, yaitu mulai dari starting new problem, siswa diberikan suatu permasalahan. Siswa menganalisis permasalahan dari merumuskan permasalahan sampai merancang percobaan. Pada tahap problem follow up, siswa dapat melakukan penyelidikan untuk menguji hipotesis. Pada tahap performance presentation, siswa dapat mengkomunikasikan hasil dari penyelidikannya dan terakhir dapat menarik kesimpulan pada tahap after conclusion of problem. Hal tersebut akan berimplikasi pada peningkatan kinerja ilmiah siswa (Ibrahim \& Nur, 2000). Sejalan dengan penelitian dari Kusumayanti (2008) menyatakan bahwa penerapan pembelajaran berbasis masalah berorentasi model rekonstruksi kognitif dapat meningkatkan pemahaman konsep fisika dan kinerja ilmiah siswa kelas $\mathrm{X}_{3}$ SMA Negeri 3 
Singaraja tahun ajaran 2007/2008. Berdasarkan uraian tersebut, maka peneliti termotivasi untuk menerapkan model pembelajaran berbasis masalah (PBL) untuk meningkatkan kinerja ilmiah dan penguasaan konsep sains siswa serta mengetahui tanggapan siswa terkait penerpan model PBL di kelas VIII C SMP Negeri 3 Singaraja, melalui sebuah Penelitian Tindakan Kelas (PTK).

Berdasarkan latar belakang, terdapat beberapa rumusan permasalahan, yaitu, 1) Apakah penerapan model PBL dapat meningkatkan kinerja ilmiah siswa kelas VIII C SMP Negeri 3 Singaraja tahun ajaran 2010/2011? 2) Apakah penerapan model PBL dapat meningkatkan penguasaan konsep sains siswa kelas VIII C SMP Negeri 3 Singaraja tahun ajaran 2010/2011? 3) Bagaimanakah tanggapan siswa di kelas VIII C SMP Negeri 3 Singaraja tahun ajaran 2010/2011 terhadap penerapan model PBL?.

\section{METODE PENELITIAN}

Penelitian ini merupakan jenis Penelitian Tindakan Kelas (Classroom Action Research) dengan menerapkan model pembelajaran PBL, yang secara umum bertujuan untuk meningkatkan kualitas pembelajaran di kelas melalui peningkatan kinerja ilmiah dan penguasaan konsep sains siswa kelas VIII C SMP Negeri 3 Singaraja.

Subjek dalam penelitian ini adalah siswa kelas VIII C SMP Negeri 3 Singaraja tahun ajaran 2010/2011, yang berjumlah 38 siswa). Objek dalam penelitian ini adalah model PBL, kinerja ilmiah, dan penguasaan konsep. Penelitian ini terdiri dari dua siklus. Siklus I meliputi kegiatan perencanaan, pelaksanaan, observasi, evaluasi, dan refleksi. Siklus II sama dengan siklus I, namun dilakukan beberapa penyempurnaan berdasarkan refleksi siklus I. Data yang diperlukan untuk penelitian di SMP Negeri 3 Singaraja, yaitu , 1) kinerja ilmiah, 2) penguasaan konsep, dan 3) tanggapan siswa terhadap penerapan model PBL dalam pembelajaran sains khususnya fisika.

Data kinerja ilmiah siswa dianalisis secara deskriptif dengan penjumlahan nilai kinerja ilmiah setiap pertemuan dibagi dengan banyaknya pertemuan. Data kinerja ilmiah siswa dikumpulkan dengan mengacu pada rubrik observasi kinerja ilmiah.

Rubrik kinerja ilmiah terdiri dari 11 komponen yaitu 1) merumuskan permasalahan, 2) merumuskan tujuan penelitian, 3) merumuskan hipotesis, 4) merancang percobaan, 5) menetapkan langkah kerja, 6) menggunakan alat dan bahan, 7) merangkai percobaan, 8) melakukan pengamatan, 9) kerjasama dalam kelompok, 10) menarik kesimpulan, 11) presentasi dan diskusi. Dengan skor maksimum 3 dan skor minimum 0 . Kinerja ilmiah untuk setiap observasi dikonversikan ke dalam skala 100 .

Nilai rerata kinerja ilmiah siswa adalah hasil bagi jumlah seluruh nilai kinerja ilmiah siswa dengan banyaknya siswa. Kinerja ilmiah siswa juga dianalisis per indikator, berdasarkan skor rata-rata $(\overline{\mathrm{X}})$, Mean Ideal $(\mathrm{MI})$, dan Standar Deviasi Ideal (SDI). MI $=1 / 2$ (skor tertinggi + skor terendah) dan SDI $=1 / 6$ (skor tertinggi + skor terendah). Siswa dikatakan tuntas jika nilai akhir kinerja ilmiah siswa $\geq 64$ yang sesuai dengan KKM di kelas VIII C SMP Negeri 3 Singaraja. Berdasarkan KTSP yang terdapat di SMP Negeri 3 Singaraja, satu kelas dikatakan tuntas jika KK $\geq 85 \%$ dan berkategori baik.

Data mengenai penguasaan konsep siswa dianalisis secara deskriptif yang diperoleh melalui LKS, kuis, tugas-tugas, dan tes penguasaan konsep. Tes penguasaan konsep dikumpulkan di akhir siklus, yang terdiri 10 soal essay, dengan skor maksimum untuk setiap soal adalah 4, dan skor minimum setiap soal adalah 0 . Nilai maksimum yang dapat dicapai siswa yaitu 40 , dan nilai minimum yaitu 0 . Nilai akhir penguasaan konsep diperoleh dari penjumlahan rata-rata nilai LKS, Tugas, Kuis dan tes penguasaan konsep dibagi 4. Penguasaan konsep siswa selanjutnya dikonversi dalam skala 100. Setelah diperoleh nilai akhir penguasaan konsep siswa, selanjutnya dicari rerata nilai penguasaan konsep siswa secara keseluruhan.

Satu kelas dikatakan tuntas jika telah mencapai $\mathrm{KK} \geq 85 \%$ dengan kategori baik, dan siswa dikatakan tuntas jika nilainya mencapai $K K M \geq 64$. Hal ini sesuai dengan KTSP yang diterapkan di SMP Negeri 3 Singaraja. Penentuan kategori untuk kinerja ilmiah dan penguasaan konsep siswa menggunakan penilaian acuan patokan (PAP).

Tanggapan siswa terhadap model PBL diukur dengan menggunakan skala Likert dalam dengan pilihan sangat setuju (SS), setuju (S), ragu-ragu (R), tidak setuju (TS) dan sangat tidak setuju (STS). Untuk tanggapan negatif pemberian skor terbalik dengan item positif. Data tanggapan siswa dianalisis secara deskriptif berdasarkan Skor rata-rata $(\bar{X})$, 
mean ideal (MI), dan standar deviasi ideal (SDI). Rumusan untuk MI dan SDI adalah : $\mathrm{MI}=1 / 2$ (Skor tertinggi + skor terendah) dan $\mathrm{SDI}=1 / 6$ (skor tertinggi + skor terendah). Total item pernyataan tanggapan adalah 15 item. Jadi dapat ditentukan skor tertinggi ideal adalah 75 dan skor terendah ideal adalah 15. Dengan demikian dapat ditentukan kategori tanggapan siswa. Kriteria keberhasilan untuk tanggapan siswa adalah jika dari analisis diperoleh hasil minimal positif.

\section{HASIL DAN PEMBAHASAN}

\section{A. Hasil}

Deskripsi pertama hasil penelitian yang akan dipaparkan adalah deskripsi nilai kinerja ilmiah siswa sebelum dan sesudah siklus I yang disajikan pada Tabel 3.

Tabel 3. Nilai Kinerja IImiah Sains Siswa Kelas VIII C Sebelum dan Sesudah Siklus I

\begin{tabular}{lcc}
\hline \multirow{2}{*}{ Keterangan } & \multicolumn{2}{c}{$\begin{array}{c}\text { Kinerja Ilmiah Sains Siswa } \\
\text { Kelas VIII C }\end{array}$} \\
\cline { 2 - 3 } & $\begin{array}{c}\text { Refleksi } \\
\text { Awal }\end{array}$ & Siklus I \\
\hline Nilai rata-rata & 67,4 & 67,9 \\
Nilai Tertinggi & 74,0 & 76,8 \\
Nilai & 64,0 & 46,5 \\
Terendah & & \\
Ketuntasan & & \\
Klaksikal (\%) & $73,7 \%$ & $76,3 \%$ \\
\hline
\end{tabular}

Berdasarkan Tabel 3 terlihat bahwa nilai rata-rata kinerja ilmiah pada siklus I sebesar 67,9, ketuntasan klasikal kinerja ilmiah mencapai 76,3\%. Berdasarkan kriteria penggolongan, nilai rata-rata kinerja ilmiah berkategori cukup. Tabel tersebut juga menunjukkan bahwa nilai rata-rata kinerja ilmiah siswa mengalami peningkatan setelah siklus I. Berdasarkan KKM tersebut, pada refleksi awal persentase siswa yang belum tuntas untuk aspek kinerja ilmiah adalah sebesar 26,3\% (10 orang) dan persentase siswa yang tuntas adalah sebesar $73,7 \%$ (18 orang). Ini berarti ketuntasan klasikal yang tercapai pada refleksi awal adalah $73,7 \%$.

Nilai kinerja ilmiah untuk siklus I bila dibandingkan dengan KKM maka persentase siswa yang belum tuntas adalah 23,7\% (9 orang), dan persentase siswa yang sudah tuntas adalah 76,3\% (29 orang). Berdasarkan kategori keberhasilan, penelitian dikatakan berhasil bila ketuntasan belajar minimal $85 \%$ dan berkategori baik. Sesuai dengan kriteria keberhasilan tersebut, maka kinerja ilmiah sains siswa pada siklus I belum memenuhi kriteria keberhasilan. Kinerja ilmiah dalam penelitian ini juga dianalisis sesuai indikator. Kinerja ilmiah ini dinilai berdasarkan 11 indikator, yaitu kinerja ilmiah di siklus I, untuk indikator 11 yaitu persentasi hasil diskusi percobaan, indikator 5 yaitu menetapkan langkah kerja, indikator 6 yaitu menggunakan alat dan bahan, serta indikator 7 yaitu merangkai percobaan berada dalam katagori cukup. Ini mengindikasikan bahwa kinerja ilmiah mengalami kelemahan pada indikator merangkai percobaan, menggunakan alat dan bahan, menetapkan langkah kerja, serta persentasi hasil diskusi.

Deskripsi kedua untuk hasil penelitian adalah deskripsi nilai penguasaan konsep siswa sebelum dan sesudah siklus I disajikan pada Tabel 4.

Tabel 4. Nilai Penguasaan Konsep Sains Siswa Kelas VIII C Sebelum dan Sesudah Siklus I

\begin{tabular}{lcc}
\hline \multicolumn{1}{c}{ Keterangan } & \multicolumn{2}{c}{$\begin{array}{c}\text { Penguasaan Konsep } \\
\text { Sains Siswa Kelas VIII C }\end{array}$} \\
\cline { 2 - 3 } & Refleksi Awal & Siklus I \\
\hline Nilai rata-rata & 62,8 & 72,6 \\
Nilai Tertinggi & 76,0 & 82,4 \\
Nilai Terendah & 64,0 & 61,1 \\
Ketuntasan & $63,2 \%$ & \\
Klaksikal (\%) & & $84,2 \%$ \\
\hline
\end{tabular}

Berdasarkan Tabel 4. rata-rata penguasaan konsep pada siklus I adalah sebesar 72,6. Jika berdasarkan kriteria penggolongan, nilai rata-rata penguasaan konsep sains siswa berada pada kategori baik yaitu terletak antara rentang 70 sampai dengan 84. Ketuntasan klaksikal sebesar $84,2 \%$. Nilai rata-rata penguasaan konsep ini, jika dibandingkan dengan nilai rata-rata penguasaan konsep sains siswa sebelum tindakan siklus I maka terdapat peningkatan nilai rata-rata penguasaan konsep.

Jika nilai penguasaan konsep siswa pada refleksi awal dibandingkan dengan Kriteria Ketuntasan Minimum (KKM) IPA yang berlaku saat ini di SMP Negeri 3 Singaraja yaitu sebesar 64, maka persentase siswa yang belum tuntas adalah $36,8 \%$ (14 orang), dan persentase siswa yang sudah tuntas adalah $63,2 \%$ (24 orang). Ini berarti, ketuntasan klasikal yang tercapai pada refleksi awal adalah $63,2 \%$. Nilai penguasaan konsep untuk siklus I bila dibandingkan dengan 
KKM maka persentase siswa yang belum tuntas adalah $15,8 \%$ (6 orang), dan persentase siswa yang sudah tuntas adalah $84,2 \%$ (32 orang). Ini berarti, ketuntasan klasikal yang tercapai pada siklus I adalah $84,2 \%$. Berdasarkan kategori keberhasilan, penelitian dikatakan berhasil jika ketuntasan belajar minimal $85 \%$ serta berkategori baik. Penguasaan konsep sains siswa pada siklus I belum memenuhi kriteria keberhasilan dari segi ketuntasan klaksikal, namun untuk kategorinya sudah memenuhi kriteria keberhasilan.

Deskripsi ketiga untuk hasil penelitian adalah deskripsi nilai kinerja ilmiah siswa kelas VIII C pada saat refleksi awal, siklus I, dan siklus II disajikan pada tabel 5 .

Tabel 5. Nilai Kinerja Ilmiah Sains Siswa Kelas VIII C Pada Saat Refleksi Awal, Siklus I, dan Siklus II

\begin{tabular}{lccc}
\hline Keterangan & \multicolumn{3}{c}{ Kinerja ilmiah Sains } \\
\cline { 2 - 4 } & $\begin{array}{c}\text { Refle } \\
\text { ksi } \\
\text { Awal }\end{array}$ & Siklus I & $\begin{array}{c}\text { Siklus } \\
\text { II }\end{array}$ \\
\hline Nilai. rata- & 67,4 & 67,9 & 79,9 \\
rata & & & \\
Nilai Tertinggi & 74,0 & 76,8 & 86,4 \\
Nilai & 64,0 & 46,5 & 40,9 \\
$\begin{array}{l}\text { Terendah } \\
\text { Ketuntasan }\end{array}$ & & $76,3 \%$ & $92,1 \%$ \\
Klaksikal(\%) & $73,7 \%$ & & \\
& & & \\
\end{tabular}

Jika rata-rata nilai kinerja ilmiah sains pada siklus II ini dibandingkan dengan nilai ratarata kinerja ilmiah sains siswa sebelum tindakan siklus I dan setelah tindakan siklus I (seperti pada Tabel 5), maka terdapat peningkatan nilai rata-rata kinerja ilmiah sains sebesar 0,46 dari saat sebelum dan sesudah tindakan siklus I, serta peningkatan sebesar 12,06 terjadi dari siklus I ke siklus II. KKM di sekolah SMP Negeri 3 Singaraja untuk mata pelajaran sains adalah sebesar 64. Berdasarkan hal tersebut, pada refleksi awal persentase siswa yang belum tuntas untuk aspek kinerja ilmiah adalah sebesar $26,3 \%$ (10 orang) dan persentase siswa yang tuntas adalah sebesar $73,7 \%$ (18 orang). Ini berarti, ketuntasan klasikal yang tercapai pada refleksi awal adalah 73,7\%. Nilai kinerja ilmiah untuk siklus I jika dibandingkan dengan KKM sains yang berlaku saat ini di SMP Negeri 3 Singaraja, maka persentase siswa yang belum tuntas adalah $23,7 \%$ (9 orang), dan persentase siswa yang sudah tuntas adalah 76,3\% (29 orang). Ini berarti, ketuntasan klasikal yang tercapai pada siklus I adalah $76,3 \%$. Jika nilai kinerja ilmiah untuk siklus II dibandingkan dengan KKM sains, maka persentase siswa yang belum tuntas adalah 7,9\% (3 orang), dan persentase siswa yang sudah tuntas adalah $92,1 \%$ (35 orang). Ini berarti, ketuntasan klasikal yang tercapai pada siklus II adalah $92,1 \%$. Nilai rata- rata kinerja ilmiah siswa pada siklus II adalah 79,9 dan KK 94,7\% dengan kategori baik. Hasil kinerja ilmiah siklus II sudah meningkat dari siklus I.

Berdasarkan kategori keberhasilan, penelitian dikatakan berhasil jika ketuntasan belajar minimal $85 \%$ dan berkategori baik. Berdasarkan kriteria keberhasilan tersebut, maka kinerja ilmiah sains siswa pada siklus II sudah memenuhi kriteria keberhasilan. Kinerja ilmiah di siklus II, semua indikator rata-rata sudah berkategori baik. Namun dari kesebelas indikator tersebut, indikator 7 yaitu merangkai percobaan memiliki skor rata-rata paling rendah yaitu 1,9 .

Deskripsi keempat untuk hasil penelitian adalah deskripsi nilai penguasaan konsep siswa sebelum dan sesudah siklus I disajikan pada Tabel 6.

\begin{tabular}{|c|c|c|c|}
\hline \multirow[t]{2}{*}{ Keterangan } & \multicolumn{3}{|c|}{$\begin{array}{c}\text { Penguasaan Konsep Sains Siswa } \\
\text { Kelas VIII C }\end{array}$} \\
\hline & $\begin{array}{l}\text { Refleksi } \\
\text { Awal }\end{array}$ & Siklus I & Siklus II \\
\hline Nilai rata-rata & 62,8 & 72,6 & 75,5 \\
\hline Nilai Tertinggi & 76,0 & 82,4 & 85,8 \\
\hline $\begin{array}{l}\text { Nilai } \\
\text { Terendah }\end{array}$ & 64,0 & 61,1 & 53,6 \\
\hline $\begin{array}{l}\text { Ketuntasan } \\
\text { Klaksikal(\%) }\end{array}$ & $63,2 \%$ & $84,2 \%$ & $94,7 \%$ \\
\hline
\end{tabular}

Jika nilai rata-rata penguasaan konsep sains pada siklus II ini dibandingkan dengan nilai rata-rata penguasaan konsep sains siswa sebelum tindakan siklus I dan setelah tindakan siklus I (seperti pada Tabel 6), maka terdapat peningkatan nilai rata-rata penguasaan konsep sains sebesar 9,73 dari saat sebelum dan sesudah tindakan siklus I, serta peningkatan sebesar 2,96 terjadi dari siklus I ke siklus II. Jika nilai penguasaan konsep siswa pada refleksi awal dibandingkan dengan KKM sains yang berlaku saat ini di SMP Negeri 3 Singaraja yaitu 
sebesar 64, maka persentase siswa yang belum tuntas adalah $36,8 \%$ (14 orang), dan persentase siswa yang sudah tuntas adalah $63,2 \%$ (24 orang). Ini berarti ketuntasan klasikal yang tercapai pada refleksi awal adalah $63,2 \%$. Nilai penguasaan konsep untuk siklus I jika dibandingkan dengan KKM sains, maka persentase siswa yang belum tuntas adalah $15,8 \%$ (6 orang), dan persentase siswa yang sudah tuntas adalah $84,2 \%$ (32 orang). Ini berarti, ketuntasan klasikal yang tercapai pada siklus I adalah $84,2 \%$.

Jika nilai penguasaan konsep siklus II dibandingkan dengan KKM sains, maka persentase siswa yang belum tuntas adalah $5,3 \%$ (2 orang), dan persentase siswa yang sudah tuntas adalah $94,7 \%$ (36 orang). Ini berarti, ketuntasan klasikal yang tercapai pada siklus II adalah 94,7\%. Rata-rata nilai penguasaan konsep sains siswa pada siklus II adalah 75,5 sudah meningkat dari siklus I dan (KK) $94,7 \%$. Berdasarkan kriteria keberhasilan, penelitian dikatakan berhasil jika ketuntasan belajar minimal $85 \%$ dan berkategori baik. Jadi, penguasaan konsep sains siswa pada siklus II sudah memenuhi kriteria keberhasilan.

Deskripsi kelima untuk hasil penelitian adalah deskripsi tanggapan siswa. Tanggapan siswa terhadap penerapan model PBL dalam pembelajaran sains dikumpulkan dengan menggunakan angket tanggapan di akhir siklus II. Jumlah angket yang disebarkan adalah 38, semuanya kembali dan layak untuk dianalisis. penggolongan tanggapan siswa pada kategori sangat positif $5,3 \%$, positif $81,6 \%$, cukup positif $13,2 \%$, kurang positif $0,0 \%$, dan sangat kurang positif $0,0 \%$. Secara umum rata-rata skor tanggapan siswa kelas VIII C SMP Negeri 3 Singaraja terhadap penerapan model pembelajaran $\mathrm{PBL}$ adalah 56,9 , yang berada pada kategori positif. Penelitian dianggap berhasil, jika tanggapan siswa terhadap model pembelajaran $\mathrm{PBL}$ minimal berkategori positif.

\section{B. Pembahasan}

Belum tercapainya kriteria keberhasilan nilai kinerja ilmiah siswa seperti yang telah ditetapkan tersebut, disebabkan oleh beberapa kendala dan permasalahan yang terjadi selama tindakan siklus I. Kendala-kendala pada siklus I, yaitu siswa mengalami kesulitan dalam mengajukan hipotesis permasalahan, merancang penyelidikan, menetapkan langkah kerja dan melakukan kegiatan percobaan, terutama pada penggunaan alat-alat percobaan dan merangkai percobaan. Ini disebabkan karena guru yang mengajar sebelumnya jarang memberikan percobaan. Jika saat mlakukan percobaan, guru sendiri yang menetapkan langkah kerja, menggunakan alat dan bahan, serta merangkai percobaan. Sehingga ketika peneliti memberikan percobaan yang menuntut siswa untuk menetapkan langkah kerja, menggunakan alat dan bahan, serta merangkai percobaan secara mandiri siswa mengalami kesulitan. Kemudian pada saat presentasi dan diskusi siswa belum berani mengemukakan pendapatnya, sehingga diskusi berjalan tidak aktif, hanya beberapa siswa yang berani mengungkapkan pendapatnya. Kinerja ilmiah pada siklus I ini, memiliki kelebihan dalam merumuskan permasalahan.

Berdasarkan kendala-kendala pada siklus I diadakan perbaikan-perbaikan untuk menanggulangi kendala pada siklus I yang nantinya akan menjadi refleksi untuk beranjak pada tindakan siklus II. Sementara pada siklus II kinerja ilmiah siswa sudah mengalami peningkatan yang signifikan, namun kinerja ilmiah mengalami sedikit kelemahan pada indikator merangkai percobaan. Hal ini disebabkan karena percobaan yang dilakukan cukup sulit dan ada beberapa siswa yang kurang menyukai pelajaran tersebut. Konsentrasi siswa pada saat pembelajaran terpecah akibat adanya kegiatan ulang tahun sekolah. Kinerja ilmiah pada siklus II ini, memiliki kelebihan dalam merumuskan permasalahan, merumuskan tujuan penelitian, dan menarik kesimpulan. Ada 3 orang siswa yang belum tuntas. Hal tersebut dikarenakan siswa ada yang tidak mengikuti proses pembelajaran akibatnya, siswa bersangkutan tidak memiliki nilai kinerja ilmiah. Pada siklus II ini, kelas VIII C tersebut sudah dikatakan tuntas karena ketuntasan klaksikalnya lebih dari $85 \%$ dan sudah berkategori baik. Hal tersebut sesuai dengan ketentuan bahwa satu kelas dianggap tuntas jika ketuntasan klaksikalnya lebih besar atau sama dengan $85 \%$ dan berkategori baik.

Selanjutnya untuk penguasaan konsep sains pada siklus I belum mencapai kriteria keberhasilan seperti yang telah ditetapkan tersebut, disebabkan oleh beberapa kendala dan permasalahan yang terjadi selama tindakan siklus I yaitu, seperti siswa merasa kesulitan untuk menjawab soal tes akhir siklus karena soal-soal ceritanya cukup panjang sehingga siswa bingung dan malas membaca soalnya. Berdasarkan kendala-kendala pada siklus I diadakan perbaikan-perbaikan untuk menanggulangi kendala pada siklus I yang 
nantinya akan menjadi refleksi untuk beranjak pada tindakan siklus II. Sesuai dengan hasil analisis, penguasaan konsep siswa mengalami peningkatan, meskipun pada siklus II masih ada 2 orang siswa yang belum tuntas. Hal tersebut disebabkan karena nilai siswa pada kuis dan tes akhir siklusnya kecil. Sering terlambat mengumpulkan tugas rumah. Siswa tersebut tidak hadir pada saat proses pembelajaran berlangsung. Akibatnya, siswa bersangkutan tidak mempunyai nilai hasil pengerjaan kuis, LKS serta kinerja ilmiah. Kelas VIII C tetap dikatakan tuntas karena sesuai dengan ketentuan bahwa satu kelas dikatakan tuntas jika ketuntasan klaksikalnya lebih besar atau sama dengan $85 \%$, serta berkategori baik.

Berdasarkan hasil belajar siswa yang diperoleh pada siklus I dan siklus II tersebut sudah menunjukkan bahwa pelaksanaan tindakan yang dilakukan mampu meningkatkan kinerja ilmiah dan penguasaan konsep siswa kelas VIII C SMP Negeri 3 Singaraja. Tanggapan siswa terhadap penerapan model pembelajaran PBL secara umum berada dalam kategori positif dengan skor rata-rata 56,9. Terdapat beberapa implikasi yang penting dalam penerapan model PBL, yaitu sebagai berikut. 1) Melalui pelaksanaan percobaan yang bertujuan untuk membuktikan hipotesis yang telah dibuat. Hal tersebut akan membuat siswa menemukan konsep sendiri secara langsung. 2) Guru membiasakan siswa untuk melaksanakan presentasi. Melalui presentasi yang baik, siswa akan terbiasa mengemukakan pendapatnya ataupun terbiasa bertanya apabila menemukan permasalahan yang masih belum dipahami. Hal tersebut akan menciptakan suatu interaksi yang baik antar siswa dengan siswa ataupun siswa dengan guru.

\section{SIMPULAN DAN SARAN}

\section{A. Simpulan}

Berdasarkan hasil penelitian dan pembahasan diuraikan simpulan sebagai berikut.

Pertama, penerapan model PBL dalam pembelajaran sains dapat meningkatkan kinerja ilmiah siswa kelas VIII C SMP Negeri 3 Singaraja tahun ajaran 2010/2011. Hal ini dapat dicermati dari nilai rata-rata kinerja ilmiah siswa pada siklus I sebesar 67,9 dengan ketuntasan klasikal $76,3 \%$ dan berkategori cukup. Pada siklus II nilai rata-rata kinerja ilmiah menjadi 79,9 dengan ketuntasan klasikal 92,1\% dan berkategori baik. Kedua, penerapan model PBL dalam pembelajaran sains dapat meningkatkan penguasaan konsep siswa kelas VIII C SMP Negeri 3 Singaraja tahun ajaran 2010/2011. Hal ini dapat dicermati dari nilai rata-rata penguasaan konsep siswa pada siklus I sebesar 72,6 dengan ketuntasan klasikal 84,2\% dan berkategori baik. Pada siklus II nilai rata-rata penguasaan konsep siswa menjadi 75,5 dengan ketuntasan klasikal 94,7\% dan berkategori baik. Ketiga, tanggapan siswa kelas VIII C SMP Negeri 3 Singaraja tahun ajaran 2010/2011 terhadap penerapan model PBL dalam pembelajaran sains berada pada kriteria positif dengan skor rata-rata 56,9.

\section{B. Saran}

Pertama, pengembangan lebih lanjut bagi peneliti lain yang ingin melaksanakan penelitian tindakan kelas dengan model PBL disarankan memperhatikah hasil refleksi pada penelitian tindakan kelas ini, sehingga nantinya akan diperoleh hasil yang lebih baik daripada penelitian yang telah dilakukan oleh peneliti. Kedua, hasil penelitian menunjukkan bahwi kinerja ilmiah siswa rata-rata masih mengalar... kesulitan dalam merangkai percobaan. Untuk itu diharapkan kepada para guru IPA hendaknya memberikan kesempatan kepada siswa untuk merangkai alat percobaan secara mandiri sehingga aspek tersebut menjadi lebih optimal.

\section{UCAPAN TERIMAKASIH}

Penulis ingin mengucapkan terimakasih yang sebesar-besarnya atas bimbingannya kepada dosen pembimbing tesis. Pembimbing I, Prof. Dr. I Wayan Suastra, M.Pd. dan pembimbing II, Drs. Rai Sujanem, M.Si

\section{DAFTAR PUSTAKA}

Brahim, T. K. 2007. Peningkatan hasil belajar sains siswa kelas IV sekolah dasar, melalui pendekatan pemanfaatan sumber daya alam hayati di lingkungan sekitar. Jurnal Pendidikan PenaburNo.09/Tahun ke-6/Desember 2007. Tersedia pada http:// www. bpkpenabur.or.id/ files/ Hal\%203749\%20 Peningkatan \% 20 Hasil \% 20 Belajar\% 20 Sains.pdf. Diakses pada tanggal 25 September 2010.

Dantes, N., Sadia, I W., \& Subagia, W. 2005. Pengembangan perangkat evaluasi proses dan hasil belajar Kurikulum Berbasis Kompetensi (KBK) rumpun pelajaran sains. Laporan Penelitian 
(tidak diterbitkan). Universitas

Pendidikan Ganesha Singaraja.

Ibrahim, M., Nur, M. 2000. Pengajaran berdasarkan masalah. Surabaya: University Press.

Kusumayanti, N K. 2008. Penerapan pembelajaran berbasis masalah berorientasi model rekonstruksi kognitif untuk meningkatkan pemahaman konsep dan kinerja ilmiah siswa kelas $X_{6}$ SMA Negeri 3 Singaraja tahun ajaran 2007/2008. Skripsi (tidak diterbitkan). Jurusan Pendidikan Fisika Universitas Pendidikan Ganesha.

Puskur. 2007. Naskah akademik kajian kebijakan kurikulum mata pelajaran IPA. Tersedia pada http://www.puskur.net/ download/ prod2007/51 Kajian\% 20 Kebijakan\%20Kurikulum \%20IPA.pdf. Diakses pada tanggal 25 September 2010.

Sanjaya, W. 2009. Kurikilum dan pembelajaran. Jakarta: Kencana Prenada Media Group.

Selçuk, G. S. 2010. The effects of problem based learning on pre-service teachers' achievement, approaches and attitudes towards learning physics. International Journal of the Physical Sciences. 5(6). 711-723. Tersedia pada http://www.academicjournals.org/lJPS/P DF/pdf2010/Jun/Sel\%C3\%A7uk pdf. Diakses pada tanggal 21 September 2010.

Sugiharti, P. 2008. Penerapan teori multiple intelligence dalam pembelajaran fisika. Jurnal Pendidikan Penabur - No.05/ Th.IV/ Desember 2008. Terdapat pada http:// www.bpkpenabur.or.id/ files/29-42 Penerapan\% 20 Teori \% 20 Multiple \% 20 Intelligence $\% \quad 20$ dalam $\% \quad 20$ Pembelajaran \% 20 Fisika.pdf. Diakses pada tanggal 10 September 2010. 